\title{
PENEGAKAN HUKUM PELANGGARAN PIDANA KAMPANYE PEMILU TAHUN 2019 DI PROVINSI BANTEN
}

\author{
Asnawi, Fakultas Hukum, Universitas Bina Bangsa, Email: \\ srgasnawi@gmail.com \\ Asih Gaduh Andriani, Fakultas Hukum Universitas Sultan Ageng Tirtayasa, \\ Email: asihgaduhandriani@gmail.com
}

doi: https://doi.org/10.24843/KS.2020.v08.i10.p15

\begin{abstract}
ABSTRAK
Pemilihan umum adalah pelaksanaan kedaulatan rakyat yang bertujuan untuk menghasilkan pemerintahan yang demokratis sesuai dengan amanat Undang-Undang Dasar Negara Republik Indonesia Tahun 1945. Masa Kampanye yang seharusnya digunakan untuk meyakinkan pemilih melalui visi, misi, program atau citra diri peserta pemilu, justru sering ditemukan adanya pelanggaran tindak pidana pemilu. Penelitian ini bertujuan untuk mengetahui penegakan hukum terhadap pelanggaran tindak pidana pemilu dalam masa kampanye yang memenuhi aspek kepastian hukum dan untuk mengetahui tindak pidana kampanye pemilu tahun 2019 di provinsi Banten. Penelitian yang dilakukan adalah tipe penelitian yuridis normatif dengan pendekatan perundang-undangan dan pendekatan kasus. Penelitian ini menggunakan data sekunder, yang terdiri dari bahan hukum primer, bahan hukum sekunder dan bahan hukum tersier. Hasil penelitian diperoleh simpulan bahwa kepastian penegakan hukum di dalam pemilu merupakan salah satu tujuan untuk menciptakan ketertiban, keamanan, dan ketentraman dalam masyarakat dan menghasilkan pemilu yang berkualitas berdasarkan asas Pemilu yang Langsung, Umum, Bebas, Rahasia, Jujur dan Adil. Apabila dilihat dari aspek kerawanan tahapan, tahapan kampanye di provinsi Banten masuk ke dalam kategori rawan tinggi. Bawaslu Banten hingga Maret 2019 mencatat jumlah pelanggaran yang terjadi pada tahapan kampanye yaitu sebanyak 11.122 kasus, yang terdiri dari 11.073 kasus pelanggaran kampanye dan 49 kasus pelanggaran pidana kampanye.
\end{abstract}

Kata Kunci: Pemilu, Tindak Pidana, Kampanye

\begin{abstract}
General elections are the implementation of people's sovereignty which aims to produce a democratic government in accordance with the mandate of the 1945 Constitution of the Republic of Indonesia. election criminal offenses. This study aims to determine law enforcement against violations of election crimes during the campaign period that meet the legal certainty aspects and to find out about the criminal offenses for the 2019 election campaign in Banten province. This research is a normative juridical research with a statutory approach and a case approach. This research uses secondary data, which consists of primary legal materials, secondary legal materials and tertiary legal materials. The results of the study concluded that the certainty of law enforcement in elections is one of the goals to create order, security and peace in society and produce quality elections based on the principles of direct, general, free, secret, honest and fair elections. When viewed from the aspect of stage vulnerability, the campaign stages in Banten province fall into the high-prone category. Bawaslu Banten until March 2019 recorded the number of violations that occurred at the campaign stage, namely as many as 11,122 cases, consisting of 11,073 cases of campaign violations and 49 cases of campaign criminal offenses.
\end{abstract}

Keywords: Election, Crime, Campaign 


\section{Pendahuluan}

\subsection{Latar Belakang Masalah}

Pemilihan umum merupakan perwujudkan pelaksanaan kedaulatan rakyat yang bertujuan untuk menghasilkan pemerintahan yang demokratis sesuai dengan amanat Undang-undang Dasar Negara Republik Indonesia Tahun 1945. Tertuang di dalam pasal 1 ayat (2) bahwa kedaulatan berada ditangan rakyat dan dilaksanakan menurut Undang-Undang Dasar. Makna dari "kedaulatan di tangan rakyat" adalah bahwa rakyat memiliki kedaulatan, hak serta kewajiban untuk memilih pemimpin secara demokratis yang akan menjalankan pemerintahan untuk melayani dan mengurus seluruh lapisan masyarakat, dan juga memilih wakil rakyat untuk mengawasi jalannya roda pemerintahan. Dengan dilaksanakannya pemilihan umum secara langsung merupakan bentuk perwujudan kedaulatan rakyat. Rakyat secara langsung dapat memilih pemimpin yang memiliki integritas untuk menjalankan roda pemerintahan baik eksekutif maupun legeslatif.

Penyelenggaraan Pemilihan umum yang diselenggarakan setiap lima tahun sekali bertujuan sebagai sarana kedaulatan rakyat untuk mewujudkan suatu demokrasi sebagai inti dalam kehidupan berbangsa dan bernegara. Melalui proses pemilu yang demokratis maka menghasilkan pemilu berkualitas dapat menghasilkan pemerintahan yang diakui oleh semua rakyat dan didukung oleh rakyat, sekaligus menentukan asas legalitas, legitimasi dan asas kredibilitas ${ }^{1}$.

Secara praktik tahapan pelaksanaan pemilu terdiri dari pendaftaran, penetapan dan pemutakhiran data pemilih, pencalonan, kampanye, Masa tenang, hari $\mathrm{H}$ pencoblosan, rekapitulasi suara hingga penetapan pasangan calon pemenang pemilu. Setiap tahapan penyelenggaraan Pemilu tersebut sangat mungkin terjadi sengketa atau pelanggaran. Dalam pelaksanaan penyelenggaraan pemilihan umum tahun 2019 berdasarkan Undang-undang Nomor 7 tahun 2017 secara umum tahapan pemilu dapat berjalan lancer sesuai dengan waktu dan jadwal yang telah ditentukan meskipun masih banyak terjadi permasalahan mulai dari penetapan DPT, penyelenggaraan yang masih banyak permasalahan, pelaksanaan kampanye masih banyak terjadi pelanggaran, dan pada saat pelaksanaan ada permasalahan kecurangan.

Dalam pelaksanaan tahapan pemilihan umum di terutama di kota atau kabupaten yang ada di provinsi banten dapat berjalan sesuai jadwal tahapan pemilu tetapi banyak terjadi pelanggaran selama tahapan pelaksanaan mulai dari pra kampanye, masa kampanye dan pasca kampanye. Dalam penelitian ini fokus pada masa kampanye pemilu di provinsi banten. Bawaslu mencatat dan menerima laporan pelanggaran administrasi dan pelanggaran pidana selama masa kampanye sebanyak 48 kasus dari 8 kota/kabupaten.

Sehingga dibentuklah suatu aturan yang digunakan sebagai panduan dalam menyelesaikan permasalahan hukum yang muncul dalam di dalam setiap tahapan pemilu. Dasar hukum dalam Pemilu 2019 adalah Undang-Undang Nomor 7 Tahun 2017. Sampai dengan saat ini masih komprehensif terkait dalam pelaksanaan pemilihan umum, karena di dalam undang-undang ini aturan mengenai pemilihan legislatif, pemilihan presiden dan wakil presiden serta penyelenggara pemilu sudah dijadikan dalam satu naskah yang sebelumnya ketiga aturan tersebut masing-masing

1 M. Rusli Karim, Pemilihan Umum Demokratis Kompetitif, Cet I, Tiara Wacana, Yogyakarta, 1991, hlm. 2 
terdapat Undang-Undangnya tersendiri. Undang-Undang ini juga terdiri dari enam buku, salah satu dari keenam buku tersebut membahas mengenai pelanggaran tindak pidana pemilu. Mengenai ketentuan pidana pemilu dibahas pada bab 2, yang terdiri dari 67 pasal yang terdapat pada pasal 488 s.d 554 .

Tindak Pidana Pemilu didefinisikan sebagai tindak pidana pelanggaran kejahatan terhadap ketentuan tindak pidana pemilu sebagaimana diatur dalam Undang-undang No.7 tahun 2017 tentang Pemilu. Dalam penyelenggaraan pemilihan umum salah satu tahapan adalah Masa Kampanye. calon Presiden dan Wakil Presiden, calon anggota Dewan Perwakilan Daerah, calon anggota Dewan Perwakilan Rakyat, dan calon anggota Dewan Perwakilan Rakyat Daerah, serta, akan melakukan kampanye dengan tujuan untuk mendapatkan dukungan sebanyak-banyaknya dari masyarakat.

Kampanye merupakan salah satu bagian dari pendidikan politik kepada masyarakat adalah dengan dilakukannya kampanye Pemilu untuk menyampaikan program visi dan misi dari peserta pemilu untuk meyakinkan masyarakat/rakyat sebagai pemilih namun kegiatan kampanye yang dilakukan haruslah dilakukan dengan mematuhi nilai dan norma yang ada di masyarakat dan juga tidak bertentangan dengan aturan hukum yang ada.

Undang-Undang Nomor 7 Tahun 2017 tentang Pemilihan Umum pasal 275 menyebutkan bahwa Kampanye Pemilu dapat dilakukan melalui beberapa cara atau metode, yaitu:

1. melakukan pertemuan terbatas;

2. melakukan pertemuan tatap muka;

3. penyebaran bahan Kampanye Pemilu kepada umum;

4. pemasangan alat peraga di tempat umum;

5. media sosial;

6. iklan media masa cetak, media masa elektronik, dan internet;

7. rapat umum;

8. debat pasangan calon tentang materi kampanye pasangan calon;

9. kegiatan lain yang tidak melanggar larangan kampanye pemilu dan ketentuan peraturan perundang-undangan.

Pelaksanaan kampanye pada Pemilihan Umum tahun 2019 berlangsung selama hampir 7 bulan, yang dimulai pada tanggal 23 September 2018 hingga 13 April 2019.Masa kampanye dalam waktu yang lama ini seharusnya dapat dimanfaatkan dengan baik oleh para peserta pemilu, pendukung dan tim kampanye masing-masing sehingga dapat menjangkau seluruh lapisan warga untuk melakukan sosialisasi visi, misi dan rencana program pembangunan pada lima tahun ke depan melalui pertarungan ide dan gagasan antar kandidat serta timnya guna mencerdaskan warga dalam menentukan pilihan yang tepat. ${ }^{2}$

${ }^{2}$ Hasil pengawasan Tahapan Pemilu 2019 oleh Badan Pengawas Pemilu (Bawaslu) Provinsi Banten, Laporan Kordiv Pengawasan 3, hlm.37, https://banten.bawaslu.go.id/pages/hasil-pengawasan-tahapan-pemilu-2019/ Diakses pada 1 Desember 2019 
Apabila dilihat dari aspek kerawanan tahapan, tahapan kampanye di provinsi Banten masuk ke dalam kategori rawan tinggi. ${ }^{3}$ Bawaslu Banten hingga Maret 2019 mencatat jumlah pelanggaran yang terjadi pada tahapan

kampanye yaitu sebanyak 11.122 kasus, yang terdiri dari 11.073 kasus dan pelanggaran kampanye 49 kasus pelanggaran pidana kampanye. ${ }^{4}$

Fungsi hukum Pidana sebagai hukum positif adalah untuk melindungi masyarakat dalam pergaulan agar tidak terjadi kekacauan. Subekti menyatakan tujuan hukum melayani tujuan Negara untuk penyelenggaraan keadilan dan ketertiban yang mendatangkan keadilan. ${ }^{5}$ Pelanggaran pidana kampanye yang dilakukan oleh para calon legislatif maupun tim sukses harus ada kepastian penegakan hukum dengan ketentuan aturan undang-undang Pidana pemilu, agar tujuan negara dalam pelayanan pemilu dapat berjalan sesuai dengan Penyelenggaraan pemilu.

\subsection{Rumusan Masalah}

1) Bagaimana penegakan hukum terhadap pelanggaran tindak pidana pemilu dalam masa kampanye yang memenuhi aspek kepastian hukum?;

2) Bagaimana tindak pidana kampanye pemilu tahun 2019 di provinsi Banten?

\subsection{Tujuan Penelitian}

1) Untuk mengetahui penegakan hukum terhadap pelanggaran tindak pidana pemilu dalam masa kampanye yang memenuhi aspek kepastian hukum;

2) Untuk mengetahui tindak pidana kampanye pemilu tahun 2019 di provinsi Banten.

\section{Metode Penelitian}

Penelitian menggunakan pendekatan yuridis normatif untuk menunjang metode ini dengan berbagai upaya mencari data sekunder yang diperlukan dalam penelitian. Metode studi atau penelitian kepustakaan yaitu dengan menginventarisasi data-data sekunder liberay researct untuk kemudian dilakukan analisis kualitatif data-data tersebut kemudian digunakan dalam penulisan meliputi bahan hukum sekunder adalah bahan hukum yang mengikat diperoleh dari buku-buku hukum, undangundang Pemilu dan lain-lain.

${ }^{3}$ Hasil pengawasan Tahapan Pemilu 2019 oleh Badan Pengawas Pemilu (Bawaslu) Provinsi Banten, Laporan Kordiv Pengawasan 2, hlm.15, https://banten.bawaslu.go.id/pages/hasil-pengawasan-tahapan-pemilu-2019/ Diakses pada 1 Desember 2019

${ }^{4}$ Hasil pengawasan Tahapan Pemilu 2019 oleh Badan Pengawas Pemilu (Bawaslu)

Provinsi Banten, Laporan Kordiv Pengawasan 3, hlm. 35-36, https://banten.bawaslu.go.id/pages/hasil-pengawasan-tahapan-pemilu-2019/ Diakses pada 1 Desember 2019

5 Kansil,1989, Pengantar Ilmu Hukum dan Tata Hukum Indonesia, Balai Pustaka, Jakarta. hlm. 41 


\section{Hasil dan Pembahasan}

Menurut konferensi South-East Asia and Pacific Conference of Jurist di Bangkok pada tanggal 15-19 Februari 1965, terdapat 6 (enam) prinsip konsep negara hukum. Salah satu dari keenam prinsip tersebut adalah prinsip pemilihan umum yang bebas ${ }^{6}$. Diselenggarakannya Pemilihan umum untuk memilih wakil rakyat secara luber dan jurdil serta demokratis. Pemilu merupakan perwujudan atau implementasi dari kedaulatan rakyat. Pemilu merupakan praktik perwujudan hak asasi manusia. Pengejawantahan penyelenggaraan pemilu yang demokratis menjadi salah satu bagian dari upaya membentuk pemerintahan yang mampu menjamin perlindungan terhadap hak asasi, rule of law, dan pembentukan institusi yang demokratis ${ }^{7}$.

Di dalam Pemilu terjadi penyerahan sebagian hak dan kekuasaan yang dimiliki oleh rakyat kepada wakil yang dipilih untuk duduk di pemerintahan dan mengurusi urusan yang menyangkut kepentingan rakyat secara umum. Sehingga dapat dikatakan bahwa mekanisme Pemilu yang digunakan dalam demokrasi secara langsung untuk memilih wakil rakyat yang dapat menjalankan pemerintahan. Hal tersebut diatas menujukan bahwa pemilihan umum menjadi sangat penting dalam kehidupan berbangsa, bernegara di Indonesia. Hampir setiap penyelenggaraan pemilu terjadi perubahan terhadap dasar hukum yang mengaturnya. Adanya evaluasi terhadap setiap pelaksanaan Pemilu untuk melihat celah-celah yang dapat diperbaiki agar tidak terjadi lagi pada Pemilu selanjutnya sehingga dapat terciptanya pemilu yang demokratis.

Esensi Pemilu adalah proses kompetisi politik untuk memperebutkan dukungan para pemilik kedaulatan (rakyat) agar mereka mau mewakilkan mandat kedaulatannya, sehingga dapat menjadi legitimasi kepada pemenang pemilu untuk menjalankan kekuasaan politik kenegaraan. Sebagai sebuah kompetisi (apalagi kompetisi politik), proses ini sangat rawan dan rentan terhadap praktek pelanggaran, baik dalam bentuk kesengajaan maupun ketidak sengajaan. Kerawanan praktek pelanggaran ini tidak hanya berpotensi terjadi pada saat pelaksanaan pemilu, bahkan dalam proses mendesain sistem pemilu terdapat peluang terjadinya pelanggaran, dalam bentuk misalnya merancang sebuah sistem pemilu yang cenderung menguntungkan pihak tertentu ${ }^{8}$.

Dalam setiap tahapan penyelenggaraan Pemilu selalu saja terdapat celah, adanya pelanggaran tindak pidana pemilu yang mencederai nilai-nilai demokrasi, sejak pada awal di mulainya masa kampanye sampai dengan tahapan pelaksanaan pemilu terakhir terjadi beberapa kali pelanggaran terhadap aturan norma hukum pemilu.

Berdasarkan pengalaman praktik penyelenggaraan pemilu selama ini, munculnya masalah-masalah penegakan hukum pemilu tersebut disebabkan beberapa faktor: pertama, batasan terjadi-tidaknya pelanggaran tidak pasti sehingga

${ }^{6}$ Miriam Budiardjo, Dasar-Dasar Ilmu Politik Edisi Revisi, Gramedia Pustaka Utama, Jakarta, 2008, hlm. 116.

${ }^{7}$ Ahsanul Minan, 2019, Refleksi Sistem dan Praktek Penegakan Hukum Pemilu di Indonesia, Jurnal Bawaslu Serial Evaluasi Penyelenggaraan Pemilu Serentak 2019: Perihal Penegakan Hukum Pemilu, Jakarta: Bawaslu, hlm. 5

8Oliver Joseph \& McLoughlin, 2019, Electoral Justice System: Assessment Guide, Stockholm: Frank, hlm. 9 
menimbulkan multitafsir yang berujung pada kontroversi; kedua, mekanisme dan prosedur penanganan pelanggaran tidak jelas sehingga penanganannya pun tidak mudah; ketiga, lembaga penegak hukum pemilu tidak disiapkan dengan baik sehingga kedodoran dalam menangani kasus-kasus yang terjadi; keempat, sanksi hukum atas terjadinya pelanggaran sangat ringan sehingga tidak memberi efek jera ${ }^{9}$.

Ketentuan tentang pelanggaran tindak pidana pemilu telah dimuat dalam berbagai dokumen, instrumen hukum, kedalam kitab Undang-undang KUHP, Undang-undang tentang pemilu dapat diatur secara tersendiri dalam kitab Undangundang khusus tentang pelanggaran tindak pidana pemilihan umum. Dilihat dari sejarah yuridis dalam konteks hukum negara-negara demokrasi modern yang telah maju sejak berabad-abad, terdapat pengaturan yang cukup memadai. Di Inggris, misalnya, sejak awal abad ke-19 telah diterbitkan the Corrupt and Illegal Practices Prevention Act, 1883. Undang-undang tersebut mengatur beberapa tindak pidana yang terkait dengan penyelenggaraan pemilu, seperti tindak pidana penyuapan, treating, pengaruh berlebihan, pengakuan palsu, dan biaya kampanye tidak sah. Proses penanganan pelanggaran tindak pidana pemilu diawali dengan membuat laporan secara tertulis, waktu dan tempat kejadian pelanggaran, nama yang terlapor dan nama yang melaporkan serta alamat tempat tinggalnya, lalu dilaporkan ke Panwaslu kecamatan lalu dilanjutkan ke Bawaslu Kabupaten atau kota, bawaslu provinsi, dan yang terakhir ke bawaslu sambil berkoordinasi dengan Kepolisian, kejaksaan dalam Gakkumdu.

Pengertian Pidana adalah bagian dari pada keseluruhan hukum yang berlaku di suatu negara, yang mengadakan dasar-dasar dan aturan untuk:10

1. Menentukan perbuatan-perbuatan mana yang tidak boleh dilakukan, yang dilarang, dengan disertai ancaman atau sangsi yang berupa pidana tertentu bagi barang siapa melanggar larangan tersebut.

2. Menentukan kapan dan dalam hal-hal apa kepada mereka yang telah melanggar larangan-larangan itu dapat dikenakan atau dijatuhi pidana sebagaimana yang telah diancamkan.

3. Menentukan dengan cara bagaimana pengenaan pidana dapat dilaksanakan apabila ada orang yang disangka telah melanggar larangan tersebut.

Secara sederhana dapat dikatakan bahwa tindak pidana pemilu dilihat dari cakupannya dapat dibedakan menjadi 3, yaitu satu, semua tindak pidana kejahatan berkaitan dengan penyelenggaraan pemilihan umum diatur dalam undang-undang pemilu. Kedua, Semua tindak pidana berkaitan penyelenggaraan pemilu diatur baik di dalamnya, maupun diluar undang-undang pemilu, misalnya di dalam undang-undang partai politik dan dalam KUHP. Ketiga, semua pelanggaran tidak pidana pada saat terjadi pemilihan umum dilangsungkan, termasuk dalam pengertian ini antara lain, pelanggaran lalu lintas, penganiayaan, kekerasan, mengganggu ketertiban umum, dan pengrusakan. Yang pertama dianggap sebagai yang paling tegas dan fokus dengan ruang lingkup cakupan yang sempit, akan tetapi hanya merujuk kepada tindak pidana yang diatur dalam undang-undang pemilu. Secara terminologis terdapat beberapa pandangan untuk tindak pidana pemilu yang pada dasarnya mengandung makna

${ }^{9}$ Topo Santoso dkk, 2006, Penegakan Hukum Pemilu: Praktik Pemilu 2004, Kajian Pemilu 2009-2014, Jakarta:Perludem, hlm. 4

${ }^{10}$ Moeljatno, 2002, Asas-Asas Hukum Pidana, Jakarta: Rineka Cipta, hlm. 1 
delik, yaitu ada yang memakai kata kejahatan, pelanggaran, atau kecurangan dalam pemilihan umum.

Berdasarkan ketentuan Pasal 280 tentang Pemilu disebutkan Perbuatan yang dikategorikan perbuatan sebagai pelanggaran tindak pidana kejahatan pada masa kampanye yaitu:

1. Menghina seseorang, agama, suku, ras, golongan, calon, dan/atau Peserta Pemilu yang lain;

2. Mengancam untuk melakukan kekerasan atau menganjurkan penggunaan kekerasan kepada seseorang, sekelompok anggota masyarakat, dan/atau Peserta Pemilu yang lain;

3. Merusak dan/atau menghilangkan alat peraga kampanye Peserta Pemilu;

4. Menggunakan fasilitas pemerintah, tempat ibadah, dan tempat pendidikan;

5. Membawa atau menggunakan tanda gambar dan/atau atribut selain dari tanda gambar dan/atau atribut Peserta Pemilu yang bersangkutan;

6. Menjanjikan atau memberikan uang atau materi lainnya kepada peserta Kampanye Pemilu;

7. Pelaksana dan/atau tim kampanye dalam kegiatan Kampanye Pemilu dilarang mengikutsertakan:

a. Hakim pada semua badan peradilan di bawah Mahkamah Agung dan Mahkamah Konstitusi;

b. Ketua, wakil ketua, dan anggota Badan Pemeriksa Keuangan;

c. Gubernur, deputi gubernur senior, dan deputi gubernur Bank Indonesia;

d. Direksi, komisaris, dewan pengawas dan karyawan BUMN/BUMD;

e. Pejabat negara bukan anggota partai politik yang menjabat sebagai pimpinan di lembaga nonstruktural;

f. Aparatur sipil negara;

g. Anggota Tentara Nasional Indonesia dan Kepolisian Negara Republik Indonesia;

h. Kepala desa beserta jajarannya;

i. Warga Negara Indonesia yang tidak memiliki hak memilih.

Tabel 1

Pelanggaran Pidana Kampanye Pemilihan Umum di Provinsi Banten Tahun 2019

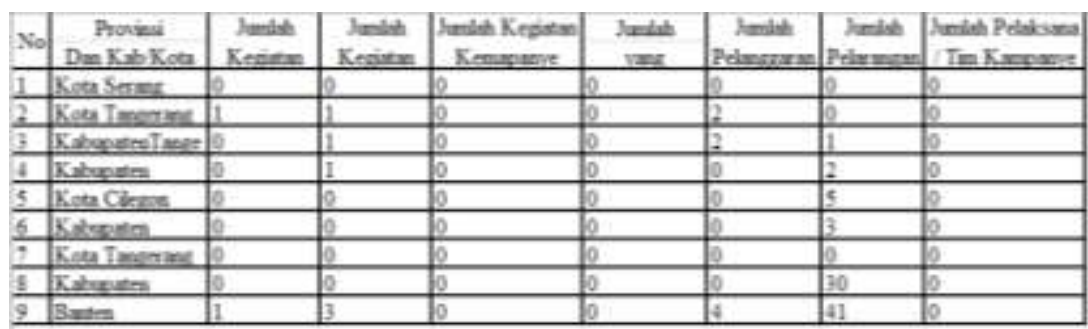

Sumber: Hasil Pengawasan Tahapan Pemilu 2019 oleh Bawaslu Provinsi Banten

Pelanggaran Pidana Kampanye yang terjadi di Provinsi Banten dari masingmasing kota/kabupaten selama masa kampanye adalah sebagai berikut:1) Kota Serang selama masa kampanye tidak terdapat pelanggaran pidana pemilu (jumlah Pelanggaran Nihil); 2) Kota Tangerang Selatan pelanggaran di tempat ibadah 1 kasus, kegiatan kampanye di tempat Pendidikan 1kasus dan pelanggaran politik uang 2 kasus (jumlah pelanggaran 4 kasus); 3) Kabupaten Tangerang pelanggaran kegiatan 
kampanye di tempat pendidikan 1 kasus, pelanggaran politik uang 2 kasus dan pelanggaran terhadap larangan kampanye 1 kasus (jumlah pelanggaran 4 kasus); 4) Kabupaten Serang pelanggaran kegiatan kampanye di tempat pendidikan 1 kasus dan pelanggaran terhadap larangan kampanye 2 kasus (jumlah pelanggaran 3 kasus) ; 5) Kota Cilegon pelanggaran terhadap larangan kampanye 5 kasus (jumlah pelanggaran 5 kasus); 6) Kabupaten Lebak pelanggaran terhadap larangan kampanye 3 kasus (jumlah pelanggaran 3 kasus); 7. Kabupaten Tangerang tidak terjadi pelanggaran pidana selama masa kampanye (jumlah pelanggaran nihil); 8) Kabupaten Pandeglang terdapat pelanggaran terhadap larangan kampanye 30 kasus (jumlah pelanggaran 30 kasus); sehingga apabila dikalkulasikan Pelanggaran Pidana pada Masa Kampanye di Provinsi Banten terdapat beberapa pelanggaran diantaranya pelanggaran kegiatan kampanye di tempat ibadah 1 kasus, pelanggaran kampanye di tempat pendidikan 3 kasus, pelanggaran politik uang 4 kasus dan pelanggaran terhadap larangan kampanye 41 kasus. Total secara keseluruhan 49 kasus.

Pelanggaran-pelanggaran tindak pidana dalam Pemilihan Umum disebabkan karena rendahnya pengetahuan dan indisipiliner para peserta Pemilu, team sukses, kader partai dan penyelenggaraannya itu sendiri, juga disebabkan kurang sosialisasi kepada pemilih. Rendahnya moralitas penegak hukum, lemahnya penegakan hukum, kelemahan dalam penegakan hukum juga bisa terjadi karena lemahnya disiplin para peserta Pemilu, team sukses, kader partai dan juga penyelenggaraan pemilu serta termasuk rendahnya disiplin aparat penegak hukum.

Mekanisme Penyelesaian pelanggaran pemilihan umum dalam hal ini tindak pidana pemilu yaitu bahwa setiap temuan maupun laporan yang masuk kepada Bawaslu dan telah dinyatakan perbuatan atau tindakan tersebut diduga merupakan tindak pidana Pemilu akan dilaporkan kepada Kepolisian Negara Republik Indonesia. Bawaslu sebelum mengambil keputusan terkait perbuatan maupun tindakan yang diduga sebagai tindak pidana Pemilu terlebih dahulu berkoordinasi dengan Gakkumdu, yang terdiri dari Kepolisian dan Kejaksaan Agung. Di dalam proses penyelesaian pelanggaran pemilu mulai dari penyelidikan, penyidikan, penuntutan dan pemeriksaan tindak pidana Pemilu dilakukan berdasarkan Kitab Undang-undang Hukum Acara Pidana (KUHAP). Namun apabila di dalam Undang-undang Nomor 7 tahun 2017 diatur berbeda, maka ketentuan yang digunakan adalah yang terdapat di dalam Undang-Undang Nomor 7 tahun 2017, hal ini berpedoman pada asas lex spesialis derogatelegi genealis maka aturan yang khusus mengalahkan aturan yang umum, maka aturan Pemilihan Umum lebih utama, sehingga apabila ada aturan yang sama maka ketentuan yang diatur KUHP dan KUHAP menjadi tidak berlaku.

Perlunya kepastian penegakan hokum dalam pelanggaran pemilu merupakan tujuan untuk menciptakan ketertiban tahapan pemilu, keamanan pelaksanaan pemilu, dan ketentraman dalam masyarakat. Jika dalam negara terjadi tindak pidana, maka langkah yang harus diambil adalah penegakan hukum pidana dengan menindak pelakunya sesuai dengan peraturan perundang-undangan yang berlaku dalam hukum pidana maupun dalam undang-undang Pemilu, untuk itu sebelum terjadi suatu tindak pidana pelanggaran Pemilu dilakukan pencegahan. 


\section{Kesimpulan}

Penegakan Hukum dalam pelanggaran tindak pidana pemilihan umum pada masa kampanye yang memenuhi aspek hukum bahwa terdapat penyebab pelanggaran diantaranya adalah kurangnya pengawasan pada masa kampanye yang dilakukan oleh badan pengawas pemilihan umum baik di tingkat Provinsi, Kabupaten/Kota, Kecamatan dan Desa/Kelurahan, bahkan banyak pelanggaran yang terjadi di kampung-kampung. Para calon atau tim suksesnya dengan bebas melakukan pelanggaran pidana pemilu karena tidak terpantau oleh petugas pengawas pemilu yang ada kelurahan/desa; Kedua koordinasi antara bawaslu/panwaslu dengan unsur penegak hukum kepolisian dipandang masih kurang berjalan dengan baik; ketiga untuk mendapatkan hasil pemilu yang lebih baik secara demokratis maka perlu adanya penegakan hukum secara professional yang berani, jujur adil tanpa ada pilih kasih.

Bentuk perbuatan dan jenis-jenis pelanggaran tindak pidana Pemilu pada masa kampanye adalah menghina lambang atau dasar negara, agama, ras, suku, partai politik lawan, menghina pribadi seseorang, calon, peserta pemilu yang lain, mengacam atau menakut-nakuti kekerasan kepada sesorang atau masyarakat, menghilangkan atau merusak alat peraga peserta pemilu atau partai yang lain, kampanye di tempat ibadah, sekolah tempat pendidikan serta menjanjikan atau memberikan uang atau barang kepada peserta pemilu. Perbuatan pelanggaran yang terjadi di Kabupaten/kota Provinsi Banten sebanyak 49 kasus pelanggaran pidana kampanye yaitu pelanggaran kampanye ditempat ibadah, tempat pendidikan, menggunakan politik uang dan pelanggaran terhadap larangan berkampanye.

\section{Daftar Pustaka}

Buku

Jimly Asshiddiqie, 2014, Pengantar Ilmu Hukum Tata Negara, Rajawali Pers, Jakarta. Kansil,1989, Pengantar Ilmu Hukum dan Tata Hukum Indonesia, Balai Pustaka, Jakarta.

Miriam Budiardjo, 2008, Dasar-Dasar Ilmu Politik Edisi Revisi, Jakarta: Gramedia Pustaka Utama.

M. Rusli Karim, 1991, Pemilihan Umum Demokratis Kompetitif, Cet I Yogyakarta: Tiara Wacana.

Moeljatno, 2002, Asas-Asas Hukum Pidana, Jakarta: Rineka Cipta.

Oliver Joseph \& McLoughlin, 2019, Electoral Justice System: Assessment Guide, Stockholm: Frank.

Topo Santoso dkk, 2006, Penegakan Hukum Pemilu: Praktik Pemilu 2004, Kajian Pemilu 2009-2014, Jakarta:Perludem.

\section{Jurnal}

Ahsanul Minan, 2019, Refleksi Sistem dan Praktek Penegakan Hukum Pemilu di Indonesia, Jurnal Bawaslu Serial Evaluasi Penyelenggaraan Pemilu Serentak 2019: Perihal Penegakan Hukum Pemilu, Jakarta: Bawaslu.

\section{Peraturan Perundang-Undangan}

Undang-Undang Negara Republik Indonesia Tahun 1945 
Undang-Undang Nomor 1 Tahun 2015 tentang Penetapan Peraturan Pemerintah Pengganti Undang-Undang Nomor 1 Tahun 2014 tentang Pemilihan Gubernur, Bupati, dan Walikota Menjadi Undang-Undang

Undang-Undang Nomor 8 Tahun 2015 tentang Perubahan AtasUndang-Undang Nomor 1 Tahun 2015 tentang Penetapan Peraturan Pemerintah Pengganti Undang-Undang Nomor 1 Tahun 2014 tentang Pemilihan Gubernur, Bupati, dan Walikota Menjadi Undang-Undang

Undang-Undang Nomor 7 Tahun 2017 tentang Pemilihan Umum (PEMILU)

\section{Website}

Hasil pengawasan Tahapan Pemilu 2019 oleh Badan Pengawas Pemilu (Bawaslu) Provinsi Banten, Laporan Kordiv Pengawasan 2, hlm.15, https://banten.bawaslu.go.id/pages/hasil-pengawasan-tahapan-pemilu-2019/

Hasil pengawasan Tahapan Pemilu 2019 oleh Badan Pengawas Pemilu (Bawaslu) Provinsi Banten, Laporan Kordiv Pengawasan 3, hlm.37, https://banten.bawaslu.go.id/pages/hasil-pengawasan-tahapan-pemilu-2019/ 